The SARS-CoV-2 pandemic has infected over 95 million people worldwide and over 2 million in Colombia. The healthcare personnel (HCP) in our country account for more than 3,800 cases and 197 deaths until January 2021 (1). Being a highly contagious virus, it has changed medical practice and exposed HCP who are at risk of becoming victims with every patient they see.

The primary routes of transmission of SARS-CoV-2 are through respiratory droplets and contact with infected patients or any nearby surfaces or objects which the patient has used. Airborne transmission of the virus is possible when conducting aerosol generating procedures (2). Among HCP, those who are more exposed to aerosols are more vulnerable to get the disease: anesthesiologists, emergency physicians, internists and intensivists, as well as ENT doctors, ophthalmologists, maxillofacial surgeons, head and neck surgeons, dentists, gastroenterologists, pulmonologists, respiratory therapists, scrub nurses, nursing staff, inter alia.

SARS-CoV-2 had a strong affinity for angiotensin II converting enzyme (ACE2) which is mainly present in the nasal and oral mucosae, where it initially replicates before invading the lung (3). The nasalpulmonary axis has been suggested as the route for the development of pneumonia in patients.

The saliva is the primary reservoir, with a high viral load ofCOVID-19 (1.2X108 infectious copies $/ \mathrm{mL}$ ). The virus may be detected in the saliva in $91.7 \%$ of the patients. A key factor to fight the disease is to reduce the viral load in the saliva and nasal secretions, in order to reduce the transmission of the disease; hence, the potential use of povidoneiodine has been suggested (3-5).

Since 1800 iodine has been recognized as an effective bactericidal agent. Then povidone-iodine was discovered in 1955, as an ideal and less toxic alternative for surgical asepsis, with a gram-positive, gram- negative, spores, fungal, viral and protozoa germicidal effect. Among the oral antiseptic agents, it has the broadest spectrum to reduce any bacterial, viral or fungal load, and more effective virucidal action than chlorhexidine or benzalkonium chloride (6). Povidone-iodine disrupts the metabolic pathways in the cell wall of microorganisms causing irreversible damage. It is a potent virucidal agent, which inhibits neuraminidase and hemagglutinin, blocking the attachment of the virus to the cell receptors and preventing the release and spread of the virus from the infected cells.

Its efficacy has been assessed in similar coronaviruses such as SARS and MERS (7). In vitro studies have shown that it also destroys SARS-CoV-2 when used for gargling or as mouth rinse at 0,23 \%, for 15 seconds, reducing the viral activity by $99.99 \%$. Experimental models have shown that povidone-iodine at a concentration of $1,25 \%$ does not alter the ciliary motility and is well tolerated by the nasal epithelium (8).

Povidone-iodine has been well tolerated in the upper airway at a dose range between $1 \%$ to $10 \%$, with no evidence of thyroid dysfunction, olfactory disorders or changes in mucociliary clearance, even with extended use (9).

The lack of solid evidence has prevented WHO and FDA approval of povidone-iodine, specifically for use in SARS CoV-2. A recent Cochrane systematic review failed to find any evidence for the systematic adoption of this intervention; however, it highlights the relatively few publications on the topic (10). Considering the efficacy of povidone-iodine with similar viruses and its routine use for nasal and oral decontamination in surgery, several countries have developed protocols for its use.

It may be considered a useful public health intervention and part of the personal protection strategy (11). For HCP, these protocols (Table 1) suggest the routine use of povidone-iodine as nasal drops 
TABLE 1. Protocols for povidone-iodine use.

\begin{tabular}{|c|c|c|c|c|c|}
\hline Reference & Nasal & $\begin{array}{l}\text { Mouth rinse or } \\
\text { gargle }\end{array}$ & Frequency & Type of patients & Healthcare Personnel \\
\hline $\begin{array}{l}\text { Pittsburgh } \\
\text { USA } \underline{(5)}\end{array}$ & $\begin{array}{l}240 \mathrm{~mL} \text { of } 0.4 \% \\
\text { povidone-iodine } \\
\text { (10 mL of } 10 \% \\
\text { Povidone-iodine in } 240 \\
\mathrm{~mL} \text { of saline solution) } \\
\text { for nasal rinse }\end{array}$ & $\begin{array}{l}\text { Mouth rinse: } 10 \mathrm{~mL} \\
\text { of } 0.5 \% \text { povidone- } \\
\text { iodine ( } 1: 20 \text { dilution } \\
\text { in distilled water) in } \\
\text { addition to adequate } \\
\text { personal protection } \\
\text { equipment. }\end{array}$ & $\begin{array}{c}\text { Use nasally and } \\
\text { orally every } 2-3 \\
\text { hours up to } 4 \text { times } \\
\text { per day. }\end{array}$ & $\begin{array}{l}\text { 1. Suspicious or } \\
\text { confirmed COVID-19. } \\
\text { 2. High-risk } \\
\text { aerosol-generation } \\
\text { procedure (nasal, } \\
\text { oral, pharyngeal } \\
\text { and pulmonary } \\
\text { procedures). } \\
\text { 3. Points of care of } \\
\text { COVID-19 patients. }\end{array}$ & $\begin{array}{l}\text { 1. Before and after exposure to } \\
\text { a patient. } \\
\text { 2. If repeated or frequent } \\
\text { exposure, use every 2-3 hours } \\
\text { up to } 4 \text { times per day when } \\
\text { delivering care to suspicious or } \\
\text { confirmed COVID-19 patients. } \\
\text { a. If high-risk aerosol- } \\
\text { generating procedures are } \\
\text { performed. } \\
\text { b. If present at a point of care } \\
\text { of COVID-19 patients. } \\
\text { c. If personal protection } \\
\text { equipment is nos available. }\end{array}$ \\
\hline $\begin{array}{l}\text { United } \\
\text { Kingdom } \\
\quad \underline{(11)}\end{array}$ & $\begin{array}{l}0.5 \% \text { Povidone-iodine } \\
\text { ( } 1 \mathrm{ml} 3 \text { of } 10 \% \\
\text { povidone-iodine in } 20 \\
\text { ml } 3 \text { of water). } \\
0.3 \mathrm{~mL} \text { in each nostril } \\
\text { using spray or syringe. }\end{array}$ & $\begin{array}{l}0.5 \% \text { Povidone-iodine } \\
1 \mathrm{ml} 3 \text { of } 10 \% \text { povidone- } \\
\text { iodine in } 20 \mathrm{ml} 3 \text { of } \\
\text { water, in addition to } \\
\text { adequate personal } \\
\text { protection equipment. } \\
\text { Use } 9 \mathrm{~mL} \text { at } 0.5 \% \text { as } \\
\text { mouth rinse for } 30 \\
\text { seconds and then } \\
\text { gargling for } 30 \text { seconds. }\end{array}$ & $\begin{array}{l}\text { Before doing a } \\
\text { procedure. }\end{array}$ & $\begin{array}{l}\text { All types of patients } \\
\text { during the pandemic. }\end{array}$ & $\begin{array}{l}\text { Use nasally and orally every 2-3 } \\
\text { hours, up to } 4 \text { times per day. }\end{array}$ \\
\hline $\begin{array}{l}\text { India } \\
\underline{(6)}\end{array}$ & $\begin{array}{l}0.5 \% \text { Povidone-iodine } \\
\text { ( } 1 \mathrm{~mL} \text { of } 10 \% \text { povidone- } \\
\text { iodine in } 20 \mathrm{~mL} \text { of } \\
\text { water or } 1 \mathrm{~mL} \text { of } 0.5 \% \\
\text { povidone-iodine) ( } 5 \% \\
\text { in } 10 \mathrm{~mL} \text { of water or } 1 \\
\mathrm{~mL} \text { of povidone-iodine) } \\
\text { (7.5\% in } 15 \mathrm{~mL} \text { of water } \\
4-5 \text { drops in each } \\
\text { nostril). }\end{array}$ & $\begin{array}{c}0.5 \% \text { Povidone-iodine } \\
1 \mathrm{~mL} \text { of } 10 \% \text { povidone- } \\
\text { iodine in } 20 \mathrm{~mL} \text { of water } \\
\text { or } 1 \mathrm{~mL} \text { of } 5 \% \text { povidone- } \\
\text { iodine in } 10 \mathrm{~mL} \text { of water } \\
\text { or } \\
1 \mathrm{~mL} \text { of } 7.5 \% \text { povidone- } \\
\text { iodine in } 15 \mathrm{~mL} \text { of } \\
\text { water } 10 \mathrm{~mL} \text { of } 0.5 \% \\
\text { povidone-iodine } \\
\text { Mouth rinse for } 30 \\
\text { seconds and then } \\
\text { gargling or keep in the } \\
\text { back of the throat for } \\
\text { another } 30 \text { seconds and } \\
\text { discard. }\end{array}$ & $\begin{array}{l}10 \text { minutes before } \\
\text { examining the } \\
\text { patient and } 2 \text { times } \\
\text { per day from the } \\
\text { day before the } \\
\text { procedure. }\end{array}$ & $\begin{array}{l}\text { Patients undergoing } \\
\text { nasal endoscopy. }\end{array}$ & Nasal endoscopy staff. \\
\hline
\end{tabular}

SOURCE: Author.

or gargle, for prophylaxis before and after exposure to patients with COVID-19. The decontamination of the oral mucosa with povidone-iodine maintains sterile conditions for up to 4 hours; hence it has been considered part of the biosecurity practices (11).

A review of clinicaltrials.gov up to March
2021, identified 20 studies with povidoneiodine in COVID-19, of which 6 have been completed and only 1 has published results: NCT04410159. According to this trial, 100 $\%$ of the patients with SARS-CoV-2 had a negative PCR-RT when gargling 3 times a day for 7 days and did not develop a severe the disease. Clinical trials are currently underway to confirm the reports from in vitro tests and pre-clinical evidence in SARS-CoV-2.

In Colombia, 8\% buccopharyngeal povidone-iodine is available. To achieve a concentration of $0.5 \%$ according to the 
suggested international protocols, use $1 \mathrm{ml}$ of $8 \%$ povidone-iodine in $15 \mathrm{ml}$ of water (1:15). The current protocols recommend gargling 3 times per day starting one day prior to the procedure until 10 minutes before starting a procedure for outpatients, and permanently for inpatients. For HCP, as prophylaxis before and after delivering care to suspicious or confirmed COVID-19 patients, or when adequate personal protection equipment is not available, up to 4 times per day throughout the COVID-19 pandemic.

Povidone-iodine is inexpensive, widely available and has stood the test of time in terms of safety. It may reduce the severity of the disease by lowering the viral load in the oral and nasal mucosae, and may reduce the risk of aerosol-generated transmission during medical procedures. The evidence currently under development, may confirm or disprove these arguments.

\section{Contribution to the study}

None declared.

\section{Financial support or sponsorship}

None declared.

\section{Conflicts of Interest}

No conflict of interest to disclose.

\section{Acknowledgment}

I want to express my gratitude to my family for their unconditional support and for the time I was absent from home to be able to complete this publication. I also thank the healthcare personnel that have risked their lives and the lives of their families to save the lives of patients during the COVID-19 pandemic every day.

\section{REFERENCES}

1. Covid-19 en personal de salud en Colombia [internet]. 2021 [citado: 19 enero 2021]. Disponible en: https://www.ins.gov.co/Noticias/ Paginas/coronavirus-personal-salud.aspx

2. Zou L, Ruan F, Huang M, et al. SARS-CoV-2 viral load in upper respiratory specimens of infected patients. N Engl] Med. 2020;382(12):1177-79. doi: http://www.doi.org/10.1056/NEJMc2001737.

3. To KK, Tsang OT, Yip CC, et al. Consistent detection of 2019 novel coronavirus in saliva. Clin Infect Dis. 2020;71(15):841-3. doi: http://www. doi.org/10.1093/cid/ciaa149.

4. Frank S, Capriotti ], Brown SM, Tessema B. Povidone-iodine use in sinonasal and oral cavities: A review of safety in the COVID-19 era. Ear Nose Throat J. 2020;99(9):586-93. doi: http:// www.doi.org/10.1177/0145561320932318.

5. Mady L], Kubik MW, Baddour K, Snyderman $\mathrm{CH}$, Rowan NR. Consideration of povidone-iodine as a public health intervention for COVID-19: Utilization as "Personal Protective Equipment" for frontline providers exposed in high-risk head and neck and skull base oncology care. Oral Oncol. 2020;105:104724. doi: http://www.doi.org/10.1016/j.oraloncology.2020.104724.

6. Khan MM, Parab SR, Paranjape M. Repurposing $0.5 \%$ povidone iodine solution in otorhinolaryngology practice in Covid 19 pandemic. Am J Otolaryngol. 2020;41(5):102618. doi: http://www.doi. org/10.1016/j.amjoto.2020.102618.

7. Eggers $M$, Koburger-Janssen $T$, Eickmann $M$, Zorn ]. In vitro bactericidal and virucidal efficacy of povidone-iodine gargle/mouthwash against respiratory and oral tract pathogens. Infect Dis Ther. 2018;7(2):249-59. doi: http:// www.doi.org/10.1007/s40121-018-0200-7

8. Frank S, Brown SM, Capriotti JA, Westover JB, Pelletier JS, Tessema B. In vitro efficacy of a povidone-iodine nasal antiseptic for rapid inactivation of SARS-CoV-2. JAMA Otolaryngol Head Neck Surg. 2020;146(11):1-5. doi: http:// www.doi.org/10.1001/jamaoto.2020.3053.

9. Parhar HS, Tasche K, Brody RM, Weinstein CS, O'Malley BW Jr, Shanti RM, Newman JC. Topical preparations to reduce SARS-CoV-2 aerosolization in head and neck mucosal surgery. Head Neck. 2020;42(6):1268-72. doi: http:// www.doi.org/10.1002/hed.26200.

10. Burton M], Clarkson JE, Goulao B, Glenny A-M, McBain A], Schilder ACM, et al. Use of antimicrobial mouthwashes (gargling) and nasal sprays by healthcare workers to protect them when treating patients with suspected or confirmed COVID-19 infection. Cochrane Database of Systematic Reviews 2020;9:CD013626. doi: http://www.doi.org/10.1002/14651858. CD013626.pub2.

11. Kirk-Bayley ], Combes ], Sunkaraneni V, et al. The use of povidone iodine nasal spray and mouthwash during the current COVID-19 pandemic may reduce cross infection and protect healthcare workers. Papers SSRN.com. 2020. doi: http://www.doi.org/10.2139/ssrn.3563092 